\title{
Adverse events of colonoscopy in a colorectal cancer screening programme with faecal immunochemical test: a population- based community-based observational study.
}

\author{
Bernard Denis $^{1,2, *}$, Isabelle Gendre ${ }^{2}$, Sarah Weber ${ }^{2}$, Philippe Perrin ${ }^{2}$ \\ ${ }^{1}$ Department of Gastroenterology, Louis Pasteur Hospital, 39 avenue de la Liberté, Colmar, France \\ ${ }^{2}$ ADECA Alsace, 122 rue de Logelbach, Colmar, France
}

\section{${ }^{*}$ Corresponding author}

Bernard DENIS

Department of Gastroenterology, Louis Pasteur Hospital, 39 avenue de la Liberté, 68024, Colmar

Cedex, France

E-mail: bernard.denis@ch-colmar.fr

Tel: 33389124101

Fax: 33389124533

\section{Abbreviations}

AE: adverse event

ASGE: American Society for Gastrointestinal Endoscopy

CRC: colorectal cancer

ESGE: European Society of Gastrointestinal Endoscopy

FIT: faecal immunochemical test

gFOBT: guaiac-based faecal occult blood test

NHS BCSP: National Health Service Bowel Cancer Screening Programme

$\mathrm{RCT}$ : randomised controlled trial

\section{Word count:}

3728 words 


\section{Contributors}

Design of the study: BD and IG. Data collection: IG, SW and PP. Data analysis: BD, IG and PP. Drafting of the paper: BD. Review of the analysis and of the content: all authors. BD is guarantor.

\section{Funding}

This study was performed as part of a quality assurance programme within the CRC screening programme in Alsace without dedicated funding. The sources of funding of ADECA Alsace, the association in charge of the programme, include the French Sickness Fund (Assurance Maladie), the French Ministry of Health and the Haut-Rhin and Bas-Rhin Administrations (Conseils Départementaux du Haut-Rhin et du Bas-Rhin). They had no role in study design, data collection, analysis, and interpretation, or writing the report.

\section{Ethical approval}

Not required.

\section{Competing interests}

None declared

Data sharing statement All deidentified participant data are available upon reasonable request from IG isabelle.gendre@adeca-alsace.fr 
medRxiv preprint doi: https://doi.org/10.1101/2020.05.09.20086389; this version posted May 12, 2020. The copyright holder for this preprint (which was not certified by peer review) is the author/funder, who has granted medRxiv a license to display the preprint in perpetuity.

It is made available under a CC-BY-NC-ND 4.0 International license .

\section{ABSTRACT}

Objectives Colonoscopy is considered a safe examination, serious complications being uncommon. Our study aimed to assess the adverse events of colonoscopy in a colorectal cancer screening programme with faecal immunochemical test (FIT) and to compare them with those of a previous programme with guaiac-based faecal occult blood test (gFOBT).

Design Retrospective observational study

Setting Population-based community-based colorectal cancer screening programme organised in Alsace, part of the national French programme, with FIT from 2015 to 2018 and gFOBT from 2003 to 2014.

Participants All residents aged $50-74$ years having a colonoscopy performed for a positive FOBT.

Main outcome measures Adverse events were recorded through prospective voluntary reporting by community gastroenterologists and retrospective postal surveys addressed to persons screened.

Results Of 9576 colonoscopies performed for a positive FIT, 6194 (64.7\%) were therapeutic. Overall, 180 adverse events were recorded (18.8\%, $95 \% \mathrm{Cl} 16.1-21.5), 114$ of them (11.9\%, $95 \% \mathrm{Cl} 9.7-14.1)$ requiring hospitalisation, $55(5.7 \%$, $95 \% \mathrm{Cl} 4.2-7.3)$ hospitalisation $>24 \mathrm{hrs}$, and $8(0.8 \%$, $95 \% \mathrm{Cl} 0.3-$ 1.4) surgery. The main complications requiring hospitalisation were perforation $(n=18,1.9 \%$, $95 \% \mathrm{Cl}$ 1.0-2.7) and bleeding $(n=31,3.2 \%$, 95\% Cl 2.1-4.4). We observed one death $(1 / 27,000$ colonoscopies). Overall, 52 persons harbouring at least one adenoma $\geq 10 \mathrm{~mm}$ were detected for one adverse event requiring hospitalisation $>24 \mathrm{hrs}$. The rate of adverse events remained stable between gFOBT and FIT programmes.

Conclusions The harms of colonoscopy in a colorectal cancer screening programme with FIT are more frequent than usually estimated, here six adverse events requiring hospitalisation $>24 \mathrm{hrs}$ (three bleedings, two perforations), one necessitating surgery and 50 minor complications per 1000 colonoscopies. The price to be paid to save lives through colorectal cancer screening programmes is higher than what is stated in most pilots. Today, comparison between series dealing with colonoscopyrelated adverse events is almost impossible. 
medRxiv preprint doi: https://doi.org/10.1101/2020.05.09.20086389; this version posted May 12,2020 . The copyright holder for this preprint (which was not certified by peer review) is the author/funder, who has granted medRxiv a license to display the preprint in perpetuity.

It is made available under a CC-BY-NC-ND 4.0 International license.

\section{Key words:}

colorectal neoplasms / prevention \& control / diagnosis

mass screening

occult blood

adverse effects

colonoscopy 
medRxiv preprint doi: https://doi.org/10.1101/2020.05.09.20086389; this version posted May 12, 2020. The copyright holder for this preprint (which was not certified by peer review) is the author/funder, who has granted medRxiv a license to display the preprint in perpetuity.

It is made available under a CC-BY-NC-ND 4.0 International license .

\section{INTRODUCTION}

Colorectal cancer (CRC) is the second most common cancer in Europe $(500,000$ estimated cases in 2018) and the second leading cause of death from malignant disease, resulting in 243,000 estimated deaths in 2018. ${ }^{1}$ Most are preventable. Several randomised controlled trials (RCTs) have demonstrated the efficacy of screening with guaiac-based faecal occult blood test (gFOBT) and flexible sigmoidoscopy on CRC mortality. ${ }^{2}$ Many countries have thus launched gFOBT CRC screening programmes. ${ }^{3}$ The efficacy of screening with a faecal immunochemical test (FIT) on CRC mortality is not demonstrated through RCTs but the superiority of FIT over gFOBT is now well established, so that many countries, including France, are now organising FIT CRC screening programmes instead of gFOBT programmes. ${ }^{3}$ However, the benefit-risk balance of these programmes is poorly evaluated. ${ }^{4}$ On one hand, none of the population-based screening programmes with gFOBT has been able to reproduce the $\mathrm{CRC}$ mortality reduction promised by the RCTs, and the expected benefit of populationbased screening programmes with FIT has not been quantified yet. On the other hand, the risk of screening trials and programmes with gFOBT and FIT is poorly evaluated. ${ }^{5}$ We demonstrated that the adverse events (AEs) of colonoscopy were underestimated in all RCTs with gFOBT and are greater in a real-world programme. ${ }^{6}$ The rate of AEs requiring hospitalisation was estimated at $7.0 \%$ and $10.0 \%$ in two FIT CRC screening pilots, notably higher than the upper limit of $5 \%$ o recommended by the European Society of Gastrointestinal Endoscopy (ESGE) ${ }^{7-9}$ Owing to the established risk factors (polypectomy, polyp size...) and since the neoplasia yield is significantly higher, AEs should be more prevalent in FIT-positive colonoscopies than in gFOBT-positive colonoscopies and, a fortiori, than in direct screening colonoscopies. ${ }^{10,11}$ Valid real-world data is needed to inform target populations, caregivers, policy-makers and funders. ${ }^{4}$

Our aim was to assess colonoscopy-related AEs in the CRC screening programme organised in France using an FIT and to compare them with those of the previous gFOBT programme.

\section{METHODS}

We retrospectively analysed the AEs of all colonoscopies performed in residents undergoing colonoscopy for a positive FOBT within the population-based CRC screening programme organised in Alsace, a region in eastern France, 1.8 million inhabitants, part of the French national programme. The FOBT was a gFOBT from September 2003 to July 2014 and a quantitative FIT from May 2015 to January 2018. 
medRxiv preprint doi: https://doi.org/10.1101/2020.05.09.20086389; this version posted May 12, 2020. The copyright holder for this preprint (which was not certified by peer review) is the author/funder, who has granted medRxiv a license to display the preprint in perpetuity.

It is made available under a CC-BY-NC-ND 4.0 International license .

\section{FOBT screening programme}

A gFOBT CRC screening programme was initiated in Alsace in 2003. Its design has been previously described. ${ }^{12,13}$ Residents aged 50-74 years (0.57 million persons) were invited by mail every other year to participate. The gFOBT (Hemoccult II) was replaced by an FIT (OC-Sensor) in May 2015. The positivity threshold was set at $30 \mu \mathrm{g}$ haemoglobin per gram $(\mu \mathrm{g} / \mathrm{g})$ faeces so that the positivity rate would be 4 to $5 \%$. People with a positive FOBT were referred for colonoscopy.

All certified endoscopists participated in the programme. Colonoscopies were performed by community gastroenterologists under usual conditions, generally with sedation/anaesthesia provided by an anaesthetist. Diagnostic colonoscopy was defined as colonoscopy without intervention or with cold biopsy whereas therapeutic colonoscopy corresponded to any procedure with polypectomy, regardless of technique. Conventional adenomas, sessile serrated adenomas/polyps and traditional serrated adenomas were considered neoplastic polyps, whereas hyperplastic polyps were nonneoplastic polyps.

\section{Adverse events recording}

AEs of all initial colonoscopies were recorded; those of surveillance colonoscopies were excluded. Information on AEs came from two main sources: prospective voluntary AE reports from gastroenterologists and seven retrospective postal surveys (every other year). For the postal surveys, all people who had undergone a colonoscopy received a mailed questionnaire with a pre-paid envelope for reply. The questionnaire asked for information on any colonoscopy-related AE and its consequences. The investigators reviewed all AEs with a phone call to the patient, and/or the general practitioner and/or the gastroenterologist. All colonoscopy reports and hospital charts concerning serious AEs were reviewed.

\section{Adverse event classification}

AEs were classified according to the American Society for Gastrointestinal Endoscopy (ASGE) lexicon. ${ }^{14}$ All events definitely, probably and possibly related to colonoscopy occurring within 30 days of the colonoscopy were taken into account, whereas events unlikely related were not. An event that prevented completion of the planned procedure and/or resulted in admission to hospital, prolongation of an existing hospital stay, another procedure needing sedation/anaesthesia, or subsequent medical consultation was considered an AE. Unplanned events that did not interfere with completion of the planned procedure or change the plan of care were considered incidents. Bleeding that occurred and was managed during the procedure was considered as an incident. We added three indicators: $\mathrm{AE}$ 
medRxiv preprint doi: https://doi.org/10.1101/2020.05.09.20086389; this version posted May 12, 2020. The copyright holder for this preprint (which was not certified by peer review) is the author/funder, who has granted medRxiv a license to display the preprint in perpetuity.

It is made available under a CC-BY-NC-ND 4.0 International license .

requiring hospitalisation, $\mathrm{AE}$ requiring $>24 \mathrm{hrs}$ hospitalisation, and $\mathrm{AE}$ necessitating surgery. The judgement on causality and severity was made by the two first authors (BD and IG).

\section{Ethical approval}

Formal ethical approval was not required because it was considered a non-interventional study by the

Est IV ethics committee (routinely collected data for the purposes of quality assurance within the screening programme).

\section{Statistical methods}

We calculated the incidence of complications per 1000 colonoscopies and $95 \%$ confidence intervals $(95 \% \mathrm{Cl})$ using the binomial distribution (Wald). The $\mathrm{Chi}^{2}$ test was used to test for statistical significance by comparisons of proportions. All statistical tests were 2-sided. The significance threshold was set at 0.05. Statistical analysis was performed with Excel 2013 (Microsoft).

\section{RESULTS}

\section{Colonoscopies and yield (Table 1)}

Overall, 434,633 persons were invited, 194,975 (44.9\%) participated and 9,450 (4.8\%) had a positive FIT with subsequent 95.9\% adherence to colonoscopy (9061 persons; mean age 63.0 years; SD 7.1). A total of 9576 colonoscopies were performed by 114 community gastroenterologists The most advanced lesion detected during therapeutic colonoscopies (64.7\% of colonoscopies) was cancer (4.7\%), neoplastic polyp (83.0\%) and non-neoplastic polyp (12.3\%). A total of 15,059 polyps were removed, that is a mean number of 2.4 polyps per therapeutic colonoscopy.

\section{Adverse events}

Overall, 180 (18.8\% colonoscopies; 95\% Cl 16.1-21.5) AEs were recorded in 178 patients. The rate of AEs did not differ between men (18.4\%०) and women (19.5\%०) $(p=0.7)$ but increased significantly with age: $13.4 \%$ in people aged 50 to $59,20.6 \%$ in those 60 to 69 , and $23.5 \%$ in those 70 to $75(p=0.02)$. The rate of $\mathrm{AEs}$ requiring hospitalisation was $11.9 \%$ (95\% $\mathrm{Cl} 9.7-14.1), 16.6 \%$ for therapeutic and $3.3 \%$ for diagnostic colonoscopies $(p<0.0001)$ (table 2$)$. It was $5.7 \%$ (95\% Cl $4.2-7.3)$ for $>24 \mathrm{hrs}$ hospitalisation, $7.3 \%$ for therapeutic and $3.0 \%$ for diagnostic colonoscopies $(p=0.008)$. It varied from $0 \%$ to $50.0 \%$ depending on the endoscopist, with no correlation with the endoscopist's adenoma detection rate or annual colonoscopy volume. The mean length of stay was 3.5 days (SD 5.5): overnight admission ( $n=59)$, stay of two or three days $(n=23)$ and stay $>3$ days $(n=32)$. The rate of AEs 
medRxiv preprint doi: https://doi.org/10.1101/2020.05.09.20086389; this version posted May 12, 2020. The copyright holder for this preprint (which was not certified by peer review) is the author/funder, who has granted medRxiv a license to display the preprint in perpetuity. It is made available under a CC-BY-NC-ND 4.0 International license.

necessitating surgery was $0.8 \%$ (95\% $\mathrm{Cl} 0.3-1.4), 0.6 \%$ for therapeutic and $1.2 \%$ for diagnostic colonoscopies ( $p=0.4)$ (table 2). No death occurred.

One $\mathrm{AE}$ requiring $>24 \mathrm{hrs}$ hospitalisation was encountered for 51.6 persons harbouring at least one adenoma $\geq 10 \mathrm{~mm}$ (58.3 one advanced adenoma). 
medRxiv preprint doi: https://doi.org/10.1101/2020.05.09.20086389; this version posted May 12, 2020. The copyright holder for this preprint (which was not certified by peer review) is the author/funder, who has granted medRxiv a license to display the preprint in perpetuity.

It is made available under a CC-BY-NC-ND 4.0 International license .

\section{Perforations}

A total of 18 perforations were recorded, that is a rate of $1.9 \%$ 。 $(95 \% \mathrm{Cl} 1.0-2.7), 3(0.9 \%$ ) for diagnostic and $15(2.4 \%$ ) for therapeutic colonoscopies (table 2). Severity was moderate in 5 cases (28\%) and severe in $8(44 \%)$. All required hospitalisation, $15(1.6 \%$ ) hospitalisation $>24 \mathrm{hrs}$, and 7 $(0.7 \%$ ) surgery (mean length of stay 12 days). Eleven $(61 \%)$ perforations were diagnosed immediately; eight (44\%) being immediately closed by the endoscopist (mean length of stay 2.5 days). The diagnosis of perforation was delayed in seven cases (39\%) (mean length of stay 8.9 days), four of them being operated on. Thirteen (72\%) perforations were caused by polypectomy, seven (39\%) of them during a second colonoscopy performed by an "expert" for a large polyp (30 to $70 \mathrm{~mm}$ ) which a first endoscopist had been unable to remove. Three perforations were caused by mechanical disruption of the sigmoid colon wall due to the progression of the colonoscope and two perforations were caused by barotrauma. Four of them were operated on.

\section{Haemorrhages}

Overall, 46 delayed haemorrhages were recorded, three were classified as an incident and 43 as an AE (4.5\%). Severity was moderate in 29 cases $(63 \%)$ and severe in four $(9 \%)$. All were caused by polypectomy, so that the rate of bleeding requiring hospitalisation was $3.2 \%, 0 \%$ o for diagnostic and $5.0 \%$ for therapeutic colonoscopies $(2.3 \%, 0 \%$ and $3.4 \%$ respectively for hospitalisation $>24 \mathrm{hrs})$ (mean length of stay 3.5 days) (table 2). Blood loss led to transfusion in nine cases $(21 \%)$, repeat endoscopy in $30(70 \%)$, endoscopic therapy in $23(53 \%)$, and surgery in none (0\%).

\section{Other adverse events (table 3)}

Two splenic injuries were observed, one operated on and one treated by embolisation. One postpolypectomy syndrome was managed conservatively. Two cases of cardiac dysrhythmia secondary to hypokalaemia caused by the bowel preparation were encountered, as were one case each of myocardial infarction, pulmonary embolism, and aspiration pneumonia. Overall, 349 (36.4\%o) incidents were recorded, so that the rate of incidents and AEs without hospitalisation was $43.3 \%$. $(95 \%$ Cl 39.3-47.4).

\section{Sources of information}

A total of $4912(51.3 \%)$ people answered the surveys. The pre-paid reply envelope was mistakenly omitted for the first FIT survey so that the answer rate was significantly reduced (33.5\%) compared to that of the second FIT survey $(70.0 \%)(p<0.00001)$. The rates of AEs, perforations and bleeding requiring hospitalisation $>24 \mathrm{hrs}$ did not differ between the two surveys, whereas the rate of incidents 
medRxiv preprint doi: https://doi.org/10.1101/2020.05.09.20086389; this version posted May 12, 2020. The copyright holder for this preprint (which was not certified by peer review) is the author/funder, who has granted medRxiv a license to display the preprint in perpetuity.

It is made available under a CC-BY-NC-ND 4.0 International license .

and AEs without hospitalisation was significantly higher at the second survey $(52.5 \%$ o vs $34.6 \%$; $\mathrm{p}<0.01$ ) (table 5). Overall, $85.1 \%$ of $\mathrm{AEs}$ requiring hospitalisation were notified by the gastroenterologists: $85.0 \%$ of perforations, $78.8 \%$ of bleedings, and $37.5 \%$ of non-gastrointestinal AEs.

\section{Comparison between gFOBT and FIT positive colonoscopies (table 1 and 3 )}

Several risk factors for complications increased significantly in the FIT period: rate of therapeutic colonoscopies, rate of proximal polyps and mean number of polyps per therapeutic colonoscopy (table 1). The overall rate of AEs decreased significantly from 23.8 to $18.8 \%$ o $(p=0.01)$, whereas that of AEs requiring hospitalisation did not differ significantly (from 10.7 to $11.9 \%, p=0.4$ ). The rates of AEs requiring hospitalisation related to therapeutic colonoscopies (from 19.8 to $16.6 \%, p=0.1$ ), of gastrointestinal AEs (from 4.3 to $5.3 \%, p=0.2$ ) and non-gastrointestinal AEs (from 0.4 to $0.6 \%, p=$ 0.4) did not differ significantly. Endoscopic management of perforations increased significantly from $30 \%$ to $61 \%(p=0.05)$ and all cases of bleeding were managed endoscopically in the FIT period.

One death occurred during the whole gFOBT and FIT period, that is one death for 27.447 colonoscopies (30-day mortality 3.6 / 100.000 colonoscopies) in a 57-year-old man.

\section{DISCUSSION}

In our population-based community-based CRC screening programme with FIT, the rate of AEs requiring hospitalisation was $11.9 \%$ overall, $1.9 \%$ for perforation and $3.2 \%$ for bleeding. The rate of AEs requiring hospitalisation $>24 \mathrm{hrs}$ was $5.7 \%$, $1.6 \%$ or perforation and $2.2 \%$ of for bleeding. The rate of AEs necessitating surgery was $0.8 \%, 0.7 \%$ for perforation and $0 \%$ ofor bleeding. Gastrointestinal AEs requiring hospitalisation and hospitalisation $>24 \mathrm{hrs}$ remained stable during the gFOBT and FIT periods despite a significant increase in several risk factors for complications: the rate of therapeutic colonoscopies increased from $48.7 \%$ to $64.7 \%$, the mean number of polypectomies per therapeutic colonoscopy from 2.0 to 2.4 , and the rate of proximal polyps from $28.9 \%$ to $35.9 \%$. Compared with the gFOBT period, the need for surgical management of AEs decreased significantly during the FIT period, from $70.0 \%$ to $38.9 \%$ for perforation and from $4.3 \%$ to $0 \%$ for bleeding. During the whole gFOBT and FIT period, we observed one death (30-day mortality 1 / 27,000 colonoscopies) and three splenic injuries (1 / 9000 colonoscopies).

The main strengths of our study are the population-based community-based setting along with the direct patient surveys. Indeed, this study is one of the first to assess the harms of colonoscopy in a 
medRxiv preprint doi: https://doi.org/10.1101/2020.05.09.20086389; this version posted May 12, 2020. The copyright holder for this preprint (which was not certified by peer review) is the author/funder, who has granted medRxiv a license to display the preprint in perpetuity.

It is made available under a CC-BY-NC-ND 4.0 International license .

population-based FIT CRC screening programme. It is also noteworthy that the details of all AEs were confirmed through direct access to hospital charts, colonoscopy reports, and, whenever necessary, phone calls to the gastroenterologist and/or the general practitioner and/or the patient. Albeit, this study is not without weaknesses. The response rate to the patients' survey was $51.3 \%$, low in comparison with the $83.7 \%$ of the NHS BCSP, ${ }^{10}$ and hospitalisation claims for the period could not be analysed, so that some AEs may have been missed, leading to a potential underestimation of the rate of AEs. However, the low response rate induced an underestimation of incidents and AEs without hospitalisation only, without consequence for AEs requiring hospitalisation, hospitalisation $>24 \mathrm{hrs}$ and surgery. Therefore, underestimation of clinically relevant AEs is probably less of an issue. Another limitation is that the postal surveys were performed every other year, so that the delay between colonoscopy and survey could be long for some patients. Likewise, this delay may have induced an underestimation of incidents and AEs without hospitalisation as patients may have forgotten some minor complications.

The harm caused by colonoscopies in our FIT programme is in line with that recently reported by two other programmes (table 4 ). ${ }^{7,8}$ Their rates of $7.0 \%$ and $10.0 \%$, along with our $11.9 \%$ rate of complications requiring hospitalisation, are notably higher than the maximum standard of $5 \%$ for 7 -day hospital admission/readmission rate recommended by the ESGE. ${ }^{9}$ They were higher than those usually reported, that is $0.5 \%$ for perforation and $2.6 \%$ or bleeding in a systematic review and metaanalysis of 21 studies along with those reported in another review of six studies on colonoscopies for stool-positive testing, i.e. $0.8 \%$ 。 for perforation and $1.9 \%$ 。 for bleeding. ${ }^{19,20}$ However, the comparison with such recommendations and aggregated figures is not pertinent as there is considerable heterogeneity in the literature. Today, it is almost impossible to compare different series dealing with colonoscopy-related AEs because indication and yield are different; AE nomenclature and sources of information are different; rates of referral for surgery are different. Even within a single programme, $A E$ rates vary twofold: e.g. from $7.2 \%{ }^{16}$ to $14.2 \%{ }^{10}$ in the English Bowel Cancer Screening Programme (BCSP).

Neoplasia yield is correlated with the risk of complication and increases significantly depending on the indication for colonoscopy (symptoms, direct screening, positive gFOBT, positive FIT). ${ }^{6,7}$ The rate of therapeutic colonoscopies varies more than twofold between series, from $32.9 \%$ in the German colonoscopy screening programme ${ }^{21}$ to around $50 \%$ in gFOBT programmes and $55 \%$ to $70 \%$ in $\mathrm{FIT}$ programmes. ${ }^{7,8}$ A way to compare different series is to analyse separately diagnostic and therapeutic 
medRxiv preprint doi: https://doi.org/10.1101/2020.05.09.20086389; this version posted May 12, 2020. The copyright holder for this preprint (which was not certified by peer review) is the author/funder, who has granted medRxiv a license to display the preprint in perpetuity.

It is made available under a CC-BY-NC-ND 4.0 International license .

colonoscopies. For diagnostic colonoscopies, our perforation and bleeding rates requiring hospitalisation were $0.9 \%$ and $0 \%$, in line with those reported in the meta-analysis $(0.4 \%$ and $0.6 \%$, respectively). ${ }^{19}$ For therapeutic colonoscopies, comparison is possible only between series having similar indications and neoplasia yields. Our 5.0\% rate of bleeding requiring hospitalisation was significantly lower than the $9.8 \%$ o reported in the meta-analysis. ${ }^{19}$ By contrast, our perforation rate was $2.4 \%$, significantly higher than the $0.8 \%$ in the meta-analysis. ${ }^{19}$ Our high rate is probably related to the high number of polyps per therapeutic colonoscopy (2.4), their large size $(5.6 \%$ of polyps $\geq 2 \mathrm{~cm})$, their proximal location (35.9\%) and the low rate of surgical resection of benign polyps (1.8\%). This level of neoplasia yield is seldom encountered, almost exclusively in FIT-positive colonoscopies. The rate of polyp(s) $\geq 2 \mathrm{~cm}$ was $2.1 \%$ in the English gFOBT BCSP. ${ }^{22}$ The rate of patients with at least one polyp $\geq$ $2 \mathrm{~cm}$ was $1.1 \%$ in the Austrian colonoscopy screening programme ( $7.4 \%$ in our programme). ${ }^{18}$

Colonoscopy techniques have evolved continuously towards more comfort, safety and ability to remove large lesions. Recent haemostasis and suture techniques allow endoscopic management of complications. Gastrointestinal AEs can be expected to be more prevalent today with AEs related to endoscopic mucosal resection of numerous, large and right-sided polyps. In fact, during our FIT period, all bleeding episodes were managed endoscopically. Moreover, the rate of perforations managed endoscopically increased significantly from $30 \%$ to $61 \%$ between the gFOBT and FIT periods. In the latter period, $39 \%$ of perforations were probably inevitable, caused by an "expert endoscopist" during large polypectomies. Almost half (45\%) were diagnosed immediately and managed endoscopically, the median length of the hospital stay being 2.5 days. These figures indicate that in recent years in Alsace community gastroenterologists have improved their performance level significantly. One might wonder whether accredited gastroenterologists could perform better. In the French and Scottish screening programmes, ${ }^{17}$ colonoscopies are performed by any certified community gastroenterologist, whereas in England and the Netherlands they are performed by a set number of accredited gastroenterologists.

Our findings suggest that the rate of AEs is significantly higher in a community-based populationbased FIT CRC screening programme than usually reported. ${ }^{19,20,23}$ The invited population should be informed for improved shared decision-making. Today, the leaflet accompanying the letter inviting the French population to participate in FIT CRC screening mentions in tiny characters that serious colonoscopy-related AEs are rare, estimated at 3\%. The word "serious" is not further explained. Maintaining this figure that underestimates by a factor of two the true prevalence of AEs is a kind of 
medRxiv preprint doi: https://doi.org/10.1101/2020.05.09.20086389; this version posted May 12, 2020. The copyright holder for this preprint (which was not certified by peer review) is the author/funder, who has granted medRxiv a license to display the preprint in perpetuity.

It is made available under a CC-BY-NC-ND 4.0 International license .

propaganda. It must be updated. We propose this statement "Colonoscopy-related adverse events, mainly bleeding and perforation, are rare. It is estimated that for 1000 colonoscopies performed for a positive FIT, six complications requiring hospitalisation longer than 24 hours and one complication necessitating surgery will occur".

The ASGE lexicon is essential as it is almost the only one to propose a standardised nomenclature for $A E s^{14}$ However, it is not satisfactory for common use: $:^{6,10,16,23}$ it is rather complex so that it has to be detailed every time it is used; it is best suited for the United States healthcare system; and certain criteria are somewhat arbitrary and open to criticism. ${ }^{6}$ Moreover, it does not define any specific method for identifying AEs. The less one seeks, the less one finds. All studies that rely on voluntary reporting underestimate actual complication rates. ${ }^{8,24}$ In our study, $15 \%$ of AEs requiring hospitalisation were not reported by gastroenterologists. In Germany, the AE rate was threefold higher in an audit than in the national colonoscopy screening registry. ${ }^{24}$ The Danish CRC screening database registered only $29.4 \%$ of recognised complications. ${ }^{8}$ A survey directed toward all patients should be mandatory for the publication of any article dealing with AEs. Moreover, should we still be calling a perforation occurring during a large polypectomy that is immediately diagnosed, closed and under surveillance $<48 \mathrm{hrs}$ in hospital a complication? There is an imperative and urgent need for a worldwide consensus on AE nomenclature, collection and reporting. An international task force should be created to formulate a series of recommendations, standardise definitions and categories, develop standardised methodology to search for AEs, and establish rules for reporting endoscopy-related AEs, for the same reasons and in the same way as were established the consensus on post-colonoscopy CRC and the STROBE statement. ${ }^{25}$ In anticipation, we adopted three simple, precise, self-explanatory indicators, all relevant for patient information: AEs requiring hospitalisation, as it is the most commonly used criterion to define clinically relevant complications; AEs requiring hospitalisation $>24 \mathrm{hrs}$, as we feel that an overnight admission for surveillance after colonoscopy (around $50 \%$ of our hospitalisations) is not a true complication; and AEs necessitating surgery.

Rate of referral for surgery must also be considered. An AE following the treatment of a large sessile polyp is attributed either to endoscopy or to surgery depending on the type of resection. Surgical resection-related morbidity-mortality is significantly higher than endoscopic polypectomy-related morbidity-mortality. ${ }^{26,27}$ Consequently, if the rate of referral for surgery for benign polyps is high, the individual endoscopist's or CRC screening programme's colonoscopy-related AE rate will be low while the overall $A E$ rate will be high. Unfortunately, the rate of referral for surgery is never specified in 
medRxiv preprint doi: https://doi.org/10.1101/2020.05.09.20086389; this version posted May 12, 2020. The copyright holder for this preprint (which was not certified by peer review) is the author/funder, who has granted medRxiv a license to display the preprint in perpetuity.

It is made available under a CC-BY-NC-ND 4.0 International license .

articles concerning colonoscopy-related AEs and results of CRC screening programmes. Yet, 1) it is far from negligible as surgery for benign colorectal polyps represents $25 \%$ of surgeries for colorectal neoplasia in the USA, ${ }^{28}$ and 2) surgery-related morbidity-mortality is almost entirely preventable, provided the endoscopist who encounters a polyp he/she cannot manage personally refers the patient to an "expert endoscopist" rather than to a surgeon. "Expert endoscopists" are able to remove endoscopically more than $90 \%$ of large polyps. ${ }^{29}$ Overall, all studies concerning AEs of colonoscopy series and CRC screening programmes should mention their rate of referral for surgery for benign polyps (or, failing that, mention their surgery-related AEs). The rate of referral for surgery was $1.8 \%$ in our programme, about half that reported in Brittany $(4.1 \%) .{ }^{30}$ Our low rate of surgical resection may partly explain our high rate of perforations following therapeutic colonoscopies.

The benefit-risk balance of $\mathrm{CRC}$ screening remains to be assessed correctly. ${ }^{4,5}$ At a time when most countries are organising CRC screening programmes, there is an urgent need for a worldwide consensus on standardised indicators. Overall, owing to the risk factors of colonoscopy-related AEs (polyp number and size) the risk is roughly proportionate to the benefit. We propose a new indicator that is the number of persons harbouring at least one adenoma $\geq 10 \mathrm{~mm}$ per $\mathrm{AE}$ requiring hospitalisation $>24 \mathrm{hrs}$ (that could be abbreviated A10+/AE24). Between our gFOBT and FIT programmes, A10+/AE24 increased from 39 to 52 . This indicator would be the cornerstone for assessment and comparison of the benefit-risk balance of different CRC screening programmes (e.g. between different countries) and strategies (e.g. between FIT and colonoscopy screening programmes). Unfortunately, this indicator cannot be calculated in any previous study, so we presented another close indicator in table 4 , that is the number of persons harbouring an advanced adenoma per $\mathrm{AE}$ requiring hospitalisation $>24 \mathrm{hrs}$.

\section{Conclusion}

AEs of FIT-positive colonoscopies are more frequent than usually reported, estimated in our programme at six AEs requiring hospitalisation $>24 \mathrm{hrs}$ (three bleedings, two perforations), one necessitating surgery, and 50 minor complications per 1000 procedures. The invited population should be openly informed of these figures. Overall, there is a lack of transparency, both in the medical literature and in the information delivered to the population about the benefit-risk balance of CRC screening. ${ }^{4}$ Almost all the gastroenterology literature states that colonoscopy is safe, serious complications being uncommon. ${ }^{19,20,23}$ Overall, gastroenterologists have an incentive to maximise the 
benefit and minimise the risk of colonoscopy. Our results indicate that the price to be paid to save lives through CRC screening programmes is higher than what is stated in most pilots. Nevertheless, the benefit-risk balance of CRC screening remains favourable, estimated in our FIT programme at 52 persons harbouring at least one adenoma $\geq 10 \mathrm{~mm}$ per $\mathrm{AE}$ requiring hospitalisation $>24 \mathrm{hrs}$. And finally, the heterogeneity of series dealing with colonoscopy-related AEs is so enormous that comparison becomes almost impossible. There is an imperative and urgent need for a worldwide consensus on $\mathrm{AE}$ nomenclature, collection and reporting.

\section{Acknowledgments}

The authors thank all the general practitioners who participated in this screening programme, the participating gastroenterologists and pathologists for their contributions and all the staff of ADECA Alsace (Association pour le dépistage du cancer colorectal en Alsace). 
medRxiv preprint doi: https://doi.org/10.1101/2020.05.09.20086389; this version posted May 12, 2020. The copyright holder for this preprint (which was not certified by peer review) is the author/funder, who has granted medRxiv a license to display the preprint in perpetuity.

It is made available under a CC-BY-NC-ND 4.0 International license .

\section{REFERENCES}

1 Ferlay J, Colombet M, Soerjomataram I, et al. Cancer incidence and mortality patterns in Europe: Estimates for 40 countries and 25 major cancers in 2018. Eur J Cancer 2018;103:356-87.

2 Holme Ø, Bretthauer M, Fretheim A, et al. Flexible sigmoidoscopy versus faecal occult blood testing for colorectal cancer screening in asymptomatic individuals. Cochrane Database Syst Rev 2013;9: CD009259. Review.

3 Senore C, Basu P, Anttila A, et al. Performance of colorectal cancer screening in the European Union Member States: data from the second European screening report. Gut 2019;68:1232-44.

4 Bretthauer M, Kalager M, Adami HO. Do's and don'ts in evaluation of endoscopic screening for gastrointestinal cancers. Endoscopy 2016;48:75-80.

5 Heleno B, Thomsen MF, Rodrigues DS, et al. Quantification of harms in cancer screening trials: literature review. BMJ 2013;347:f5334. Review.

6 Denis B, Gendre I, Sauleau EA, et al. Harms of colonoscopy in a colorectal cancer screening programme with faecal occult blood test: a population-based cohort study. Dig Liver Dis 2013;45:47480.

7 Arana-Arri E, Imaz-Ayo N, Fernández MJ, et al. Screening colonoscopy and risk of adverse events among individuals undergoing fecal immunochemical testing in a population-based program: A nested case-control study. United European Gastroenterol J 2018;6:755-64.

8 Mikkelsen EM, Thomsen MK, Tybjerg J, et al. Colonoscopy-related complications in a nationwide immunochemical fecal occult blood test-based colorectal cancer screening program. Clin Epidemiol 2018;10:1649-55.

9 Kaminski MF, Thomas-Gibson S, Bugajski M, et al. Performance measures for lower gastrointestinal endoscopy: a European Society of Gastrointestinal Endoscopy (ESGE) Quality Improvement Initiative. Endoscopy 2017;49:378-97.

10 Rutter MD, Nickerson C, Rees CJ, et al. Risk factors for adverse events related to polypectomy in the English Bowel Cancer Screening Programme. Endoscopy 2014;46:90-7.

11 Robertson DJ, Lee JK, Boland CR, et al. Recommendations on Fecal Immunochemical Testing to Screen for Colorectal Neoplasia: A Consensus Statement by the US Multi-Society Task Force on Colorectal Cancer. Gastroenterology 2017;152:1217-37. 
medRxiv preprint doi: https://doi.org/10.1101/2020.05.09.20086389; this version posted May 12, 2020. The copyright holder for this preprint (which was not certified by peer review) is the author/funder, who has granted medRxiv a license to display the preprint in perpetuity.

It is made available under a CC-BY-NC-ND 4.0 International license .

12 Denis B, Ruetsch M, Strentz P, et al. Short-term outcomes of the first round of a pilot colorectal cancer screening programme with guaiac based faecal occult blood test. Gut 2007;56:1579-84.

13 Denis B, Gendre I, Perrin P. Participation in four rounds of a French colorectal cancer screening programme with guaiac faecal occult blood test: a population-based open cohort study. $J$ Med Screen 2015;22:76-82.

14 Cotton PB, Eisen GM, Aabakken L, et al. A lexicon for endoscopic adverse events: report of an ASGE workshop. Gastrointest Endosc. 2010;71:446-54.

15 Portillo I, Idigoras I, Bilbao I, et al. Colorectal cancer screening program using FIT: quality of colonoscopy varies according to hospital type. Endosc Int Open 2018;6:E1149-E1156.

16 Lee TJ, Rutter MD, Blanks RG, et al. Colonoscopy quality measures: experience from the NHS Bowel Cancer Screening Programme. Gut 2012;61:1050-7.

17 Quyn AJ, Fraser CG, Stanners G, et al. Scottish Bowel Screening Programme colonoscopy quality - scope for improvement? Colorectal Dis 2018;20:277-83

18 Ferlitsch M, Reinhart K, Pramhas S, et al. Sex-specific prevalence of adenomas, advanced adenomas, and colorectal cancer in individuals undergoing screening colonoscopy. JAMA 2011;306:1352-8.

19 Reumkens A, Rondagh EJ, Bakker CM, et al. Post-Colonoscopy Complications: A Systematic Review, Time Trends, and Meta-Analysis of Population-Based Studies. Am J Gastroenterol 2016;111:1092-101.

20 Lin JS, PiperM, Perdue LA, et al. Screening for Colorectal Cancer: An Updated Systematic Review for the US Preventive Services Task Force: Evidence Synthesis No. 135. Rockville,MD: Agency for Healthcare Research and Quality; 2016. AHRQ publication 14-05203-EF-1.

21 Pox CP, Altenhofen L, Brenner $\mathrm{H}$, et al. Efficacy of a nationwide screening colonoscopy program for colorectal cancer. Gastroenterology 2012;142:1460-7.

22 Lee TJ, Rees CJ, Nickerson C, et al. Management of complex colonic polyps in the English Bowel Cancer Screening Programme. Br J Surg 2013;100:1633-9.

23 Ko CW, Riffle S, Michaels L, et al. Serious complications within 30 days of screening and surveillance colonoscopy are uncommon. Clin Gastroenterol Hepatol 2010;8:166-73.

24 Adler A, Lieberman D, Aminalai A, et al. Data quality of the German screening colonoscopy registry. Endoscopy 2013;45:813-8. 
medRxiv preprint doi: https://doi.org/10.1101/2020.05.09.20086389; this version posted May 12, 2020. The copyright holder for this preprint

(which was not certified by peer review) is the author/funder, who has granted medRxiv a license to display the preprint in perpetuity.

It is made available under a CC-BY-NC-ND 4.0 International license.

25 Rutter MD, Beintaris I, Valori R, et al. World Endoscopy Organization Consensus Statements on Post-Colonoscopy and Post-Imaging Colorectal Cancer. Gastroenterology 2018;155:909-25.

26 Hassan C, Repici A, Sharma P, et al. Efficacy and safety of endoscopic resection of large colorectal polyps: a systematic review and meta-analysis. Gut 2016;65:806-20.

27 de Neree Tot Babberich MPM, Bronzwaer MES, Andriessen JO, et al. Outcomes of surgical resections for benign colon polyps: a systematic review. Endoscopy 2019;51:961-72.

28 Peery AF, Cools KS, Strassle PD, et al. Increasing Rates of Surgery for Patients With Nonmalignant Colorectal Polyps in the United States. Gastroenterology 2018;154:1352-60.

29 Hassan C, Repici A, Sharma P, et al. Efficacy and safety of endoscopic resection of large colorectal polyps: a systematic review and meta-analysis. Gut 2016;65:806-20.

30 Le Roy F, Manfredi S, Hamonic S, et al. Frequency of and risk factors for the surgical resection of non-malignant colorectal polyps: a population-based study. Endoscopy 2016;48:263-70. 
medRxiv preprint doi: https://doi.org/10.1101/2020.05.09.20086389; this version posted May 12, 2020. The copyright holder for this preprint (which was not certified by peer review) is the author/funder, who has granted medRxiv a license to display the preprint in perpetuity.

It is made available under a CC-BY-NC-ND 4.0 International license .

Table 1: Comparison between the two periods of screening with guaiac-based faecal occult blood test and quantitative faecal immunochemical test

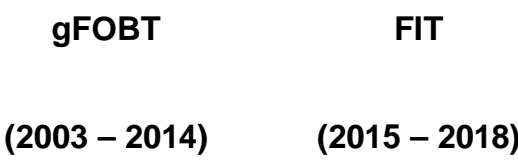

\section{Population}

\begin{tabular}{lccc}
\hline Number of people & 17,152 & 9061 & - \\
& & & \\
\hline Mean age (SD) years & $62.6(7.0)$ & $63.0(7.1)$ & $<0.001$ \\
& & & \\
\hline Men $\mathrm{n}(\%)$ & $9525(55.5)$ & $5452(60.2)$ & $<0.001$ \\
& & & \\
\hline Postal survey participation $\mathrm{n}(\%)$ & $11.519(67.2)$ & $4605(50.8)$ & $<0.001$
\end{tabular}

\section{Colonoscopies}

\begin{tabular}{|c|c|c|c|}
\hline Number of colonoscopies & 17,871 & 9576 & - \\
\hline Therapeutic colonoscopies n (\%) & $8700(48.7)$ & $6194(64.7)$ & $<0.001$ \\
\hline Invasive cancer n (PPV) & $1086(6.3)$ & $469(5.2)$ & $<0.001$ \\
\hline Advanced adenoma $n$ (PPV) & $3957(23.1)$ & $3209(35.4)$ & $<0.001$ \\
\hline Adenoma $\geq 10 \mathrm{~mm} \mathrm{n}$ (PPV) & $3630(21.2)$ & $2840(31.3)$ & $<0.001$ \\
\hline Adenoma n (PPV) & $6431(37.5)$ & $5002(55.2)$ & $<0.001$ \\
\hline Non neoplastic polyps n (PPV) & $1637(9.5)$ & $783(8.6)$ & 0.02 \\
\hline \multicolumn{4}{|l|}{ Polyps } \\
\hline Number of polyps & 18,443 & 15,553 & - \\
\hline Number of polypectomies & 17,614 & 15,059 & - \\
\hline
\end{tabular}




\begin{tabular}{|c|c|c|c|}
\hline $\begin{array}{l}\text { Mean number of polypectomies per therapeutic } \\
\text { colonoscopy (SD) }\end{array}$ & $2.0(1.6)$ & $2.4(2.0)$ & $<0.001$ \\
\hline Proximal polyps $\mathrm{n}$ (\% of polyps) & $5336(28.9)$ & $5591(35.9)$ & $<0.001$ \\
\hline Polyps $\geq 2 \mathrm{~cm} \mathrm{n} \mathrm{( \%} \mathrm{of} \mathrm{polyps)}$ & $1588(8.6)$ & $864(5.6)$ & $<0.001$ \\
\hline Surgery for benign polyps $\mathrm{n}$ (\% per persons) & $247(1.4)$ & $161(1.8)$ & 0.04 \\
\hline \multicolumn{4}{|l|}{ Complications } \\
\hline Incidents* $\mathrm{n}(\% \circ)$ & $618(34.6)$ & $349(36.4)$ & 0.4 \\
\hline Adverse events* $\mathrm{n}(\% \circ)$ & $425(23.8)$ & $180(18.8)$ & 0.01 \\
\hline Mild $^{*}$ AEs n (\%०) & $342(19.1)$ & $123(12.8)$ & 0.001 \\
\hline Moderate $^{*}$ AEs n (\%o) & $57(3.2)$ & $40(4.2)$ & 0.2 \\
\hline Severe $^{\star}$ AEs n (\%०) & $26(4.5)$ & $17(1.8)$ & 0.5 \\
\hline AEs without hospitalisation and incidents $\mathrm{n}(\%)$ & $852(47.7)$ & $415(43.3)$ & 0.1 \\
\hline AEs requiring hospitalisation $n(\% \circ)$ & $191(10.7)$ & $114(11.9)$ & 0.4 \\
\hline AEs requiring hospitalisation $>24 \mathrm{hrs} n(\% \circ)$ & $94(5.3)$ & $55(5.7)$ & 0.6 \\
\hline AEs necessitating surgery $n(\%)$ & $19(1.0)$ & $8(0.8)$ & 0.6 \\
\hline Perforations n (\%o) & $20(1.1)$ & $18(1.9)$ & 0.1 \\
\hline Bleeding $\mathrm{n}(\% \circ)$ & $69(3.9)$ & $43(4.5)$ & 0.4 \\
\hline
\end{tabular}

* according to American Society for Gastrointestinal Endoscopy (ASGE) lexicon [15]

AE: adverse event; FIT: faecal immunochemical test; gFOBT: guaiac-based faecal occult blood test; PPV: positive predictive value; SD: standard deviation 
Table 2: Classification of complications and their severity during the faecal immunochemical test period

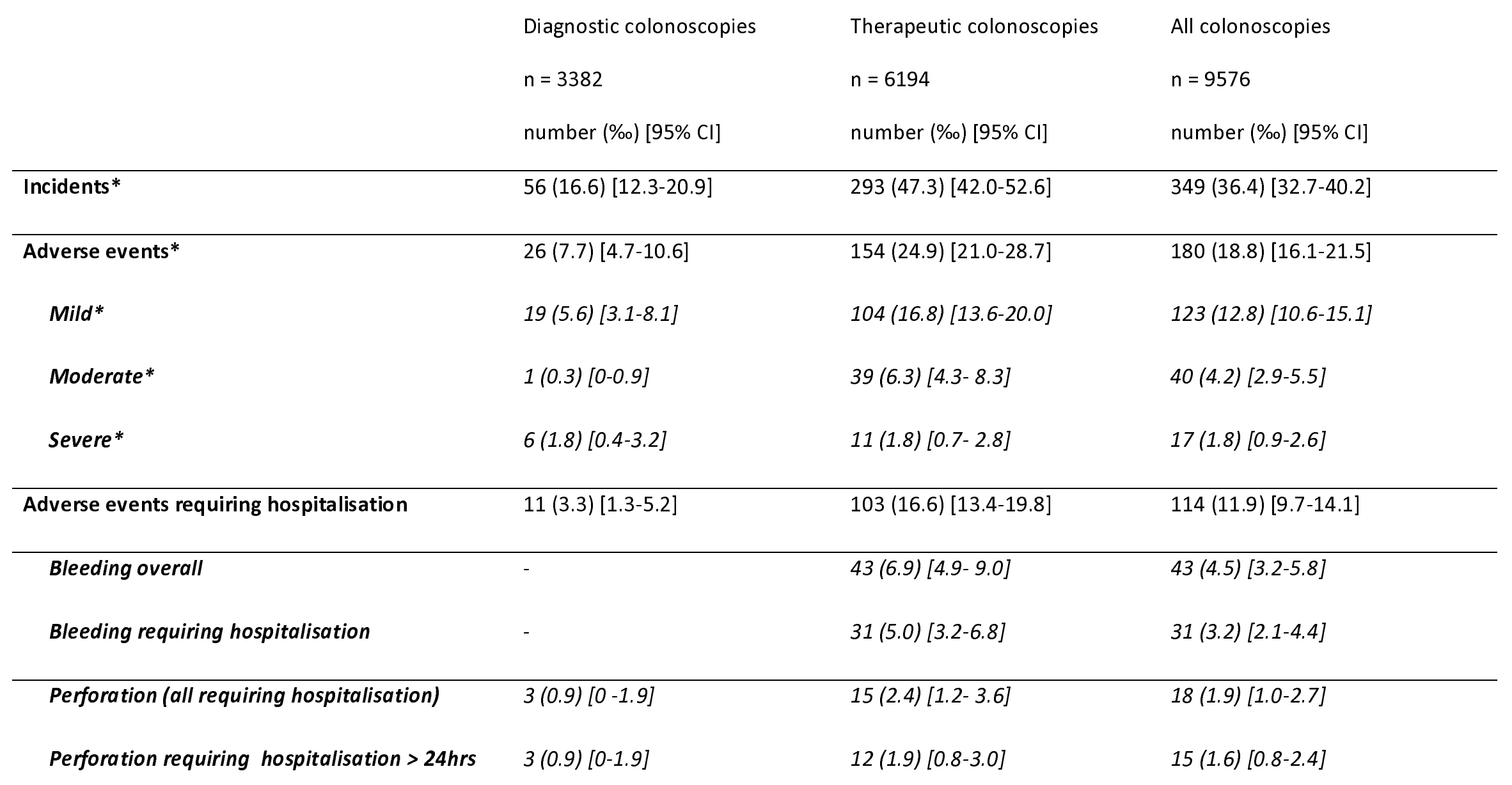

* according to American Society for Gastrointestinal Endoscopy (ASGE) lexicon [15] 
Table 3: Adverse events requiring hospitalisation during the two periods of screening with guaiacbased faecal occult blood test and quantitative faecal immunochemical test

$$
\begin{array}{cc}
\text { gFOBT }(2003-\mathbf{2 0 1 4}) & \text { FIT }(\mathbf{2 0 1 5} \mathbf{- 2 0 1 8 )} \\
\mathrm{n}=17,871 \text { colonoscopies } & \mathrm{n}=9576 \text { colonoscopies } \\
\text { number }(\%)[95 \% \mathrm{Cl}] & \text { number }(\%)[95 \% \mathrm{Cl}]
\end{array}
$$

\begin{tabular}{llll}
\hline GASTROINTESTINAL AES & $175(9.8)[8.3-11.2]$ & $104(10.9)[8.8-12.9]$ & 0.4
\end{tabular}

\begin{tabular}{lccc}
\hline Bleeding & $54(3.0)[2.2-3.8]$ & $31(3.2)[2.1-4.4]$ & 0.8 \\
Perforation & $20(1.1)[0.6-1.6]$ & $18(1.9)[1.0-2.7]$ & 0.1
\end{tabular}
Post-polypectomy syndrome
$7(0.4)[0.1-0.7]$
$4(0.4)[0-0.8]$
0.9

Splenic injury

$1(0.1)[0-0.2]$

$2(0.2)[0-0.5]$

0.3

Surveillance

$80(4.5)$ [3.5-5.5]

$46(4.8)[3.4-6.2]$

0.7

Other

$13(0.7)[0.3-1.1]$

$3(0.3)[0-0.7]$

0.2

NON-GASTROINTESTINAL AES

$16(0.9)[0.5-1.3]$

$10(1.0)[0.4-1.7]$

0.7

\section{TOTAL}

$191(10.7)$ [9.2-12.2]

$114(11.9)[9.7-14.1]$

0.4

AE: adverse event; FIT: faecal immunochemical test; gFOBT: guaiac-based faecal occult blood test 
Table 4: Adverse events requiring hospitalisation in different population-based studies of colorectal cancer screening programmes

\begin{tabular}{|c|c|c|c|c|c|c|c|c|}
\hline Screening & Country & Years & $\begin{array}{c}\text { Number } \\
\text { colonoscopies }\end{array}$ & $\begin{array}{c}\text { Polypectomy } \\
\text { rate }\end{array}$ & Adverse events & Perforation & Bleeding & AA/AE24 \\
\hline FIT & Basque country $^{7,15}$ & $2009-14$ & 39254 & $70 \%$ & $10.0 \%$ & $2.7 \%$ & $6.2 \%$ & 38 \\
\hline \multirow[t]{2}{*}{ gFOBT } & England (BCSP) ${ }^{16}$ & $2006-9$ & 36460 & $47 \%$ & $7.2 \%$ & $0.9 \%$ & $4.1 \%$ & $?$ \\
\hline & England (BCSP) ${ }^{10}$ & $2006-12$ & 130831 & $53 \%$ & $14.2 \%$ & $0.6 \%$ & $6.5 \%$ & $?$ \\
\hline colonoscopy & Austria $^{18}$ & $2007-10$ & 44350 & $34 \%$ & $2.5 \%$ & $0.1 \%$ & $1.2 \%$ & 9 \\
\hline
\end{tabular}

AA/AE24: Number of persons harbouring at least one advanced adenoma per adverse event requiring hospitalisation $>24 \mathrm{~h}$ 
medRxiv preprint doi: https://doi.org/10.1101/2020.05.09.20086389; this version posted May 12, 2020. The copyright holder for this preprint (which was not certified by peer review) is the author/funder, who has granted medRxiv a license to display the preprint in perpetuity.

It is made available under a CC-BY-NC-ND 4.0 International license .

Table 5: Differences between the two surveys on screening with quantitative faecal immunochemical test

1st survey $\quad 2^{\text {nd }}$ survey $\quad p$ Number of colonoscopies $\mathrm{n}=4907 \quad \mathrm{n}=4669$ Response rate $\mathrm{n}(\%)$ $1646(33.5 \%) \quad 3266(70.0 \%)<0.01$ AEs without hospitalisation and incidents $\mathrm{n}(\% \circ)$ $170(34.6) \quad 245(52.5)<0.01$ AEs requiring hospitalisation $\mathrm{n}(\% \circ)$ $53(10.8)$ $61(13.1)$

AE: adverse event 